\title{
The Effects of Key Macroeconomic Variables on Market Capitalization in Selected Emerging Markets: Post 2007- 08 Crisis Era
}

Çağlar Karadumana,

a Anadolu University, Turkey, caglarkaraduman@anadolu.edu.tr, https://orcid.org/0000-0002-4956-6684

\section{ARTICLE INFO}

\section{Research Article}

2021, Vol. 3(1), 1-9

e-ISSN 2667-5927

Article History:

Received: 12.07 .2020

Revised: 02.12.2020

Accepted: 02.12.2020

Available Online: 25.01 .2021

JEL Code: C33, C36, 016

Keywords: stock market, emerging markets, GMM
The Effects of Key Macroeconomic Variables on Market Capitalization in Selected Emerging Markets: Post 2007-08 Crisis Era

Abstract

Stock market developments are of high importance both for developed and developing countries. Determinants of stock market development are studied under two different sets of variables in the literature: institutional structure and key macroeconomic variables. While the studies regarding the first provided rather consistent results, the studies regarding the second have not come to a well-accepted consensus, at least for the majority of the key macroeconomic variables. This study aims to find out post-crisis determinants of stock market development between 2009-2018 for 31 emerging markets, using generalized method of moments (GMM) technique in three separate models. The estimation results show that the exchange rate and financial development index have positive relation with market capitalization ratio along with the rule of law index as an institutional factor.

To cite this document: Karaduman, Ç. (2021). The Effect of Key Macroeconomic Variables on Market Capitalization in Selected Emerging Markets: Post 2007-08 Crisis Era, BILTURK, The Journal of Economics and Related Studies, 3(1), 1-9. doi: 10.47103/bilturk.768362 


\section{Introduction}

Stock markets are particularly important for emerging markets as they provide the opportunity of a fruitful platform for long-term economic growth. That platform is materialized through increases in market liquidity and more efficient mobilization of savings in an economy (Jensen and Murphy, 1990; Levine, 1991; Greenwood and Smith, 1997). The literature on stock market development has mainly focused on two perspectives in terms of determinants: macroeconomic variables and qualitative measures of institutions.

Scores of macroeconomic variables have been used in literature to find out the relationship between those and stock market development including economic development, interest rate, inflation rate, level of openness, exchange rate and capital flows. In contrast to institutional measures the literature presents inconsistent results in terms of macroeconomic determinants depending on corresponding subjects, time period and methodology. Thus, an effort to increase the information stock on this topic seems necessary and valuable.

It is an important fact that the literature on stock market development consists of mainly panel data analysis, which generally comes with the cost of loss in countryspecific effects while providing information on mutual characteristics of certain country groups. However, generalized method of moments (GMM) being one of the panel data techniques, makes it possible to derive information from shorter time periods while tackling possible endogeneity problem.

This study focuses on key macroeconomic variables of interest rate, inflation rate, trade openness and credit in determination of stock market capitalization ratio for the 2009-2018 period and 31 emerging countries using system GMM technique.

\section{Literature}

The literature on stock market development has mainly focused on two kind of variable sets in terms of determinants: macroeconomic variables and qualitative measures of institutions. In terms of the macroeconomic perspective economic growth, economic development, maturity of banking sector, interest rates, inflation rates, exchange rates, trade openness and foreign direct investment flows constitute the largest part of the related literature as determinants of stock market development (Dornbusch and Fisher, 1980; Boyd et al., 1996; Levine 1997, 2005; Niroomand et al., 2014; Ho, 2017, 2018). The literature, in contrast to the qualitative measures, is far from reaching a consensus on the directional and magnitudinal effects of certain macroeconomic variables, as Ho and lyke (2017) put. While empirical research on the topic present inconclusive results probably varying due to i) type of data, ii) time period, iii) estimation technique and iv) subjects, there stands an expected effect of every macroeconomic variable on stock market development under certain conditions. 
The effects of economic growth and economic development on stock market are expected to be positive. The reason is that while economy grows the fixed costs of running a financial system decreases either as per capita or as proportion of GDP. Similarly, economic development brings a deeper financial system that increases the effectiveness of the system thereby again decreasing the relative fixed cost (Greenwood and Smith, 1997; Boyd and Smith 1998).

The maturity of banking sector and financial development is expected to be an important variable regarding the fact that both banking sector and stock market are important parts of a financial system. However, this often creates the impression of possible rivalry, making banking sector and stock market substitutes (see DeAngelo and Rice, 1983; Stiglitz, 1985 and Bhide, 1993). Under such an assumption the expected effect of the maturity of banking system on stock market becomes negative. An exactly opposite perspective of banking sector and stock market being complementary is also possible as Levine (2005) put. Of course, under that assumption the expected effect is also reversed.

In terms of interest rates, the results presented in different studies seem to be consistent. The theoretical expectation is a negative relationship between interest rates and stock prices based on the assumption that when central banks increase interest rates the cost of borrowing increases, causing a fall in demand for bonds with lower yield rates and vice versa (Spiro, 1990; Mok, 1993). Still, there are completely different cases as there are various factors affecting expectations and therefore market reactions (Shiller, 1988; Asprem, 1989; Barsky, 1989).

Inflation is expected to create disinclining effects on stock market because of the uncertainty and the disruption in price signals. A possible explanation for non-linear effects stated in the literature (see Choi et al., 1996; Boyd et al., 2001) in terms of inflation may be stemming from the phenomenon that the level of disruption increases exponentially as inflation rate increases. On the contrary, decreases in inflation are often achieved by well-designed macroeconomic policies.

A strong relation between exchange rates and stock market development is the standard expectation. That is because as a currency appreciates foreign investors' expected return decreases and vice versa as Dornbusch and Fisher (1980) put. Currency appreciation causes an increase in the capital outflow, thus reducing the effect of monetary policy on real exchange rate. However, there is the possibility that the effect of monetary policy on real exchange rate may be reversed under the condition of strong link between stock prices and aggregate demand, as Gavin (1989) stressed. 


\section{Variables and Methodology}

This study aims on the macroeconomic determinants of stock market capitalization ratio (gathered from the World Bank databank online) for the 10-year period of 2009-2018 using annual data and for 31 emerging markets, namely Argentina, Brazil, Chile, China, Colombia, Croatia, Egypt, Greece, Hungary, India, Indonesia, Kazakhstan, Korea, Malaysia, Mauritius, Mexico, Morocco, Nigeria, Oman, Panama, Peru, Poland, Portugal, Russia, Saudi Arabia, Singapore, South Africa, Spain, Thailand, Turkey and Vietnam. The country selection was made regarding solely to the availability of data.

Due to the limitation arising from limited observations, only a couple of explanatory variables were to be chosen to be included in a single model. Thus, some of the explanatory variables were introduced into models one-by-one while others were kept fixed as key determinants. To prevent omitted variable bias, the rule of law index was introduced into estimated models. Fixed and partially introduced variables are shown in the table below.

Table 1: Fixed and partially introduced variables

\begin{tabular}{ll}
\hline \hline \multirow{2}{*}{ Fixed Variables } & $\begin{array}{l}\text { GDP Per Capita Growth } \\
\text { Rule of Law Index } \\
\text { Exchange Rate }\end{array}$ \\
\hline \hline \multirow{2}{*}{ Partially Introduced Variables } & $\begin{array}{l}\text { Financial Development Index } \\
\text { Consumer Price Index } \\
\text { Lending Rate of Interest }\end{array}$ \\
\hline \hline
\end{tabular}

All the variables used in estimations were in natural logarithm form. Three models with the following mathematical forms were estimated;

Model I: $\ln M C R=\beta_{1}+\beta_{2} \ln G D P P C g_{i t}+\beta_{3} \ln R o L_{i t}+\beta_{4} \ln E x c_{i t}+$ $\beta_{5} \operatorname{lnFinDev}{ }_{i t}+\beta_{6} X_{i t}^{\prime}+\varphi_{t}+u_{i t}$

Model II: $\ln M C R=\beta_{1}+\beta_{2} \ln G D P P C g_{i t}+\beta_{3} \ln R o L_{i t}+\beta_{4} \ln E x c_{i t}+$ $\beta_{5} \ln C P I_{i t}+\beta_{6} X^{\prime}{ }_{i t}+\varphi_{t}+u_{i t}$

Model III: $\ln M C R=\beta_{1}+\beta_{2} \ln G D P P C g_{i t}+\beta_{3} \ln R o L_{i t}+\beta_{4} \ln E x c_{i t}+$

$$
\beta_{5} \ln L R I_{i t}+\beta_{6} X^{\prime}{ }_{i t}+\varphi_{t}+u_{i t}
$$

where the MCR is the market capitalization ratio, the GDPPCg is the growth rate of GDP per capita, the RoL is the Rule of Law Index, the Exc is the official exchange rate as local currency unit per USD (period average), the FinDev is the Financial Development Index, the CPI is the consumer price index and lastly the LRI is the lending rate of interest. The terms $X^{\prime}{ }_{i t}, \varphi_{i t}$ and $u_{i t}$ represent the vector of control variables, the year dummies and the error term, respectively. The data for MCR, GDPPCg, RoL, Exc, CPI and LRI data were gathered from World Bank Databank while FinDev series were gathered from International Monetary Fund Database. 
The number of groups being greater than the time period and the number of observations being relatively smaller necessitated the utilization of GMM method (Arellano and Bond, 1991; Arellano and Bover, 1995 and Blundell and Bond, 1998). As the number of observations are limited to 10 years, tests for cross-sectional dependency were not considered. STATA 15.1 software with the command xtabond2 (see Roodman, 2009) was used for the estimations and the corresponding diagnostics.

\section{Estimation Results}

To determine whether difference GMM or system GMM to be employed, the specified model was estimated using fixed effects (FE) estimation and pooled OLS estimation (P-OLS) for comparison with difference GMM estimation results.

Table 2: InMCR Coefficient estimation results for FE, POLS and Diff. GMM

\begin{tabular}{|c|c|c|c|c|c|c|}
\hline \multirow[b]{2}{*}{$\begin{array}{c}\text { Estimated } \\
\text { Model } \\
\end{array}$} & \multicolumn{2}{|c|}{ Model I } & \multicolumn{2}{|c|}{ Model II } & \multicolumn{2}{|c|}{ Model III } \\
\hline & $\begin{array}{l}\text { Coefficient } \\
\text { for InMCR }\end{array}$ & $\begin{array}{l}P> \\
|t| \\
\end{array}$ & $\begin{array}{l}\text { Coefficient } \\
\text { for InMCR }\end{array}$ & $\begin{array}{l}P> \\
|t|\end{array}$ & $\begin{array}{c}\text { Coefficient } \\
\text { for InMCR } \\
\end{array}$ & $\begin{array}{l}P> \\
|t| \\
\end{array}$ \\
\hline P-OLS & $\begin{array}{c}.9623211 \\
(.0236083)\end{array}$ & .000 & $\begin{array}{c}.9771527 \\
(.0207258)\end{array}$ & .000 & $\begin{array}{c}.973082 \\
(.0219043)\end{array}$ & .000 \\
\hline FE & $\begin{array}{c}.4526313 \\
(.0732781)\end{array}$ & .000 & $\begin{array}{c}.4480983 \\
(.0720204)\end{array}$ & .000 & $\begin{array}{c}.4011884 \\
(.0691765)\end{array}$ & .000 \\
\hline Diff. GMM & $\begin{array}{c}.6717632 \\
(.1280909)\end{array}$ & .000 & $\begin{array}{c}.5043553 \\
(.1069882)\end{array}$ & .000 & $\begin{array}{c}.5347545 \\
(.1149079)\end{array}$ & .000 \\
\hline
\end{tabular}

Heteroskedasticity consistent standard errors are in parentheses.

The comparison of the results revealed that the estimated coefficient of InMCR in difference GMM method is much closer to the one of FE estimation, making the selection of system GMM method reasonable. The utilization of system GMM also prevented data loss that would happen otherwise due to differencing. The estimated one-step system GMM results are represented below. The code for the estimation included correction to overcome heteroskedasticity and autocorrelation while using orthogonal deviations to further minimize data loss. Also, the estimations were limited to one instrument for each variable and lag distance in order to overcome the large number of instruments problem. Along with lagged series of the dependent variable, the growth rate of GDP per capita was treated as endogenous as it is expected to have correlation with the dependent variable in terms of past and possibly present errors.

The estimation results showed that for the 2009-2018 period in the countries in hand, ceteris paribus, the rule of law index and exchange rate were positively 
Karaduman, Ç. (2021). The Effect of Key Macroeconomic Variables on Market Capitalization in Selected Emerging Markets: Post 2007-08 Crisis Era, BILTURK, The Journal of Economics and Related Studies, 3(1), 1-9. doi: $10.47103 /$ bilturk.768362

associated with market capitalization ratio at $95 \%$ level while the index for financial development was estimated to be in positive relation with the MCR at the $90 \%$ level. A percentage increase in the rule of law index created .17 and .18 percent increase in MCR according to Model II and Model III respectively. Similarly, a percentage increase in exchange rate created $.03, .02$ and .03 increase in MCR in Model I, Model II and Model III respectively.

Table 3: The system GMM estimation results

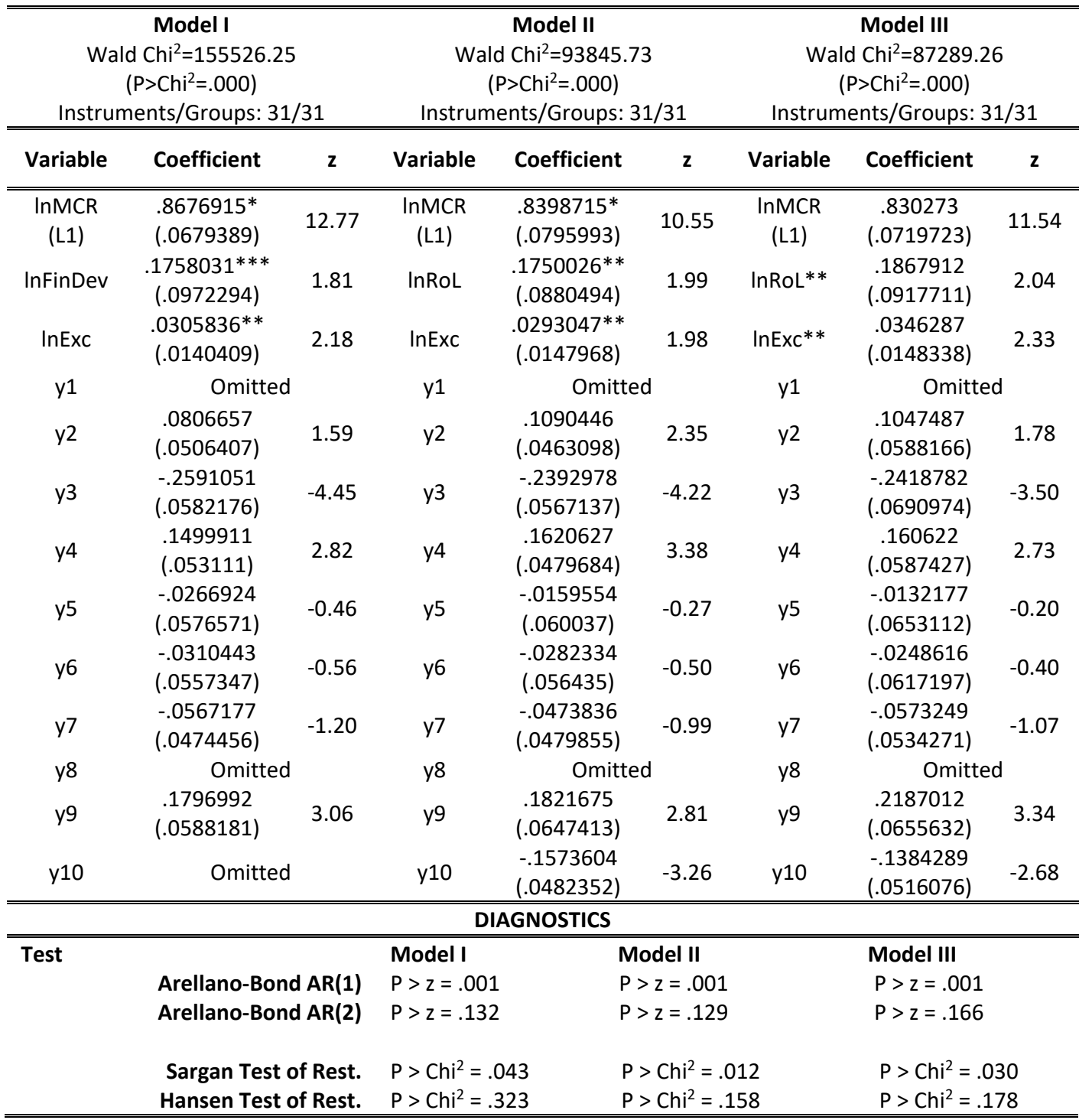

1) $\quad * \mathrm{p}<0.01 ; * * \mathrm{p}<0.05 ; * * * \mathrm{p}<0.10$

2) Only statistically significant values were represented.

3) Heteroskedasticity consistent standard errors are in parentheses. 
It is worth noting that according to the models, in 2011 (y3), MCR was $29.57 \%$, $27.02 \%$ and $27.35 \%$ lower than the year before, most probably because of the fall in stock markets around the world in August that year due to European sovereign debt crisis to Spain and Italy. The highest jump was caught in the year 2017 (y9) with $19.67 \%, 19.97 \%$ and $24.44 \%$ increase according to the models ${ }^{1}$. Wald chisquared values showed that the best model was Model I in terms of overall explanatory power.

The diagnostics proved that there was no second-order serial correlation in error term implying that the moment conditions were correctly specified. Hansen and Sargan test results produced good results in terms of overidentification problems.

\section{Conclusion}

Among the fundamental macroeconomic variables, only the institutional factors proxied as rule of law index and exchange rate proxied by official rate (LCU per USD) were found to be highly significant and in positive relation with market capitalization ratio. In addition, financial development index was also found to be in positive relation with MCR but at a weaker significancy level. The results showed that institutional factors and exchange rates are particularly important for emerging markets. This may be interpreted as investors both from local and foreign origins pay higher attention to risks in emerging markets and presumably the strong need for foreign investments in those countries makes institutional factors and exchange rates much more important for them.

The results, in consistency with the literature proved that the process of institutionalization is an important part of structural reforms in emerging countries. Also, the results regarding the exchange rate seem to be sufficient to conclude that countries with overvalued currencies are more likely to suffer from the losses in effecting market capitalization.

\footnotetext{
${ }^{1}$ The formula used for the calculation is: $\left(e^{\beta}-1\right) \times 100$.
} 


\section{References}

Arellano, M. and Bond, S. (1991). Some tests of specification for panel data: Monte Carlo evidence and an application to employment equations, Review of Economic Studies 58: 277-297.

Arellano, M. and Bover, O. (1995). Another look at the instrumental variable estimation of error-components models, Journal of Econometrics 68: 29-51.

Asprem, M. (1989). Stock prices, asset portfolios and macroeconomic variables in ten European countries. Journal of Banking and Finance 13(4): 589-612.

Barsky, R. (1989). Why don't the prices of stocks and bonds move together? American Economic Review 79(5): 1132-1145.

Bhide, A. (1993). The hidden costs of stock market liquidity, Journal of Financial Economics 34: 1-51.

Blundell, R., and Bond, S. (1998). Initial conditions and moment restrictions in dynamic panel data models, Journal of Econometrics 87: 115-143.

Boyd, J. H., Levine, R. and Smith, B.D. (1996). Inflation and financial market performance, Manuscript, Federal Reserve Bank of Minneapolis.

Boyd, J. H. and Smith, B. D. (1998). Capital market imperfections in a monetary growth model, Economic Theory 11: 241-273.

Boyd, J. H., Levine, R., \& Smith, B. D. (2001). The impact of inflation on financial sector performance. Journal of Monetary Economics, 47(2), 221-248.

Choi, S., Smith, B. and Boyd, J. H. (1996). Inflation, Financial Markets, and Capital Formation. Federal Reserve Bank of St. Louis Review 78, 41- 58.

DeAngelo, H. and Rice, E. (1983). Anti-takeover amendments and stockholder wealth, Journal of Financial Economics 11: 329-360.

Dornbusch, R. and S. Fisher, (1980). Exchange Rates and the Current Account, American Economic Review 70, No. 5, December 960-971.

Eisenhauer, J. G. (2003) Regression through the origin, Teaching Statistics 25:3.

Gavin, M. (1989). The stock market and exchange rate dynamics, Journal of International Money and Finance Vol 8: 2, Elsevier.

Greenwood, J. and Smith, B. (1997). Financial markets in development, and the development of financial markets, Journal of Economic Dynamics and Control 21(1): 145-181.

Ho, Sin-Yu. and lyke, N. B. (2017). Determinants of stock market development: a review of the literature, Studies in Economics and Finance 34(1): 143-164. 
Jensen, M. C. and Murphy, K. J. (1990). Performance pay and top-management incentives, Journal of Political Economy 98(2): 225-264.

Levine, R. (1991). Stock markets, growth, and tax policy, Journal of Finance 46, pages 1445-1465.

Levine, R. (1997). Financial development and economic growth: Views and agenda, Journal of Economic Literature 35: 688-726.

Levine, R. (2005). Finance and growth: Theory and evidence. Philippe Aghion and Steven Durlauf (ed.), 2005. Handbook of Economic Growth, vol. 1:1.

Mok, H. M. K. (1993). Causality of interest rate, exchange rate and stock prices at stock market open and close in Hong Kong. Asia Pacific Journal of Management 10: 123-143.

Niroomand, F., Hajilee, M. and Al-Nasser, O. M. (2014). Financial market development and trade openness: evidence from emerging economies, Applied Economics 46(13): 1490-1498.

Roodman, D. (2009). How to do Xtabond2: An Introduction to Difference and System GMM in Stata, The STATA Journal 9: 1.

Shiller, R. J. (1988). Causes of changing in financial market volatility, The Federal Reserve Bank of Kansas City 2(1): 1-22.

Spiro, P. S. (1990). The impact of interest rate changes on stock prices volatility, Journal of Portfolio Management 16(2): 63-68.

Stiglitz, J. E. (1985). Credit markets and the control of capital, Journal of Money, Credit, Banking 17(2): 133-152. 